\title{
Ellipsis of Subject Pronouns in Laskar Pelangi Translation Niji no Shonentachi
}

\author{
Adis Kusumawati, Universitas Airlangga
}

\begin{abstract}
The ellipsis of sentence elements commonly happens both in Bahasa Indonesia and Japanese language.In Japanese, the common sentence element in which ellipsis occurs is the sentence element that is categorized into nouns, such as subject and object.Although noun ellipsis also occurs in Bahasa Indonesia, the frequency is not as many as in Japanese. This study, with the qualitative research method, analyzes the subject pronoun ellipsis that occurs in Indonesian novel Laskar Pelangi that is translated into Japanese. The subject matter is related to the characteristics of subject pronoun ellipsis in translation, such as the ellipsis types, position of ellipsis controller constituents, as well as functions and semantic roles of the subjects in which ellipsis occurs.From the analysis results, it can be concluded that the ellipsis controller constituentsof subject pronoun can be on the right or left side of controlled constituent.Thus, it proves that in Japanese, the anaphoric and cataphoric ellipses are possible, although the number of cataphoric ellipsis is less than the anaphoric ellipsis. The functions and semantic roles owned by the ellipsis controller are limited to the functions and roles owned by the subject pronouns.
\end{abstract}

Keywords: ellipsis; semantic role; subject pronoun; syntactic function; translation

\section{Introduction}

Translation from a language to another is a phenomenon that is commonly found in all part of life in the globalization era. Translation requires to communicate, to transfer knowledge, and to transfer culture. Various factors to regard in text translation activities includes the grammar and target language culture factors. Bahasa Indonesia and Japanese language own different grammar which affects the translation result of both languages, one of the differences is the sentence structure of both languages' sentences, that is the predicate in Japanese is always at the end of the sentence (S-O-P) while the predicate in Bahasa Indonesia is placed after the subject (S-P-O). The different position of the sentence elements also affects the cohesion and coherence in translation. In translation, there is the clause merging (both coordinately and subordinately) and sentence merging process. This merging process causes the existence of similar elements in a sentence or a discourse. The repetition of two similar elements in a sentence or a discourse can reduce the efficiency in terms of information delivery. One of the syntax tools that can reduce the inefficiency is ellipsis. Ellipsis, which is also known as deletion, is the process of omitting a part of a construction. Ellipsis is also a way to reduce the redundancy in a sentence or discourse without reducing the obtained meaning (Kridalaksana, 2001). Reference is the matter that can be separated from the deletion process since return is one of the requirements for the occurrence of ellipsis. The returned constituent can have the reference inside and outside of language context (Kuno, 1978). The study of this paper focuses on the target language (TL) that has ellipsis. The matter to study is related to the characteristics of subject pronoun ellipsis in translation, such as the ellipsis types, position of ellipsis controller constituents, as well as functions and semantic roles of the subjects in which ellipsis occurs.

\section{Method of the Study}

According to Holmes, based on its nature, the study of translation can be divided into two, that is the theoretical translation study and the descriptive translation study. The descriptive translation study can be divided into three types, that is 1) the translation function-oriented translation study, 2) the translation process-oriented translation study, and 3) the translation product-oriented translation study (Holmes in Sorvali, 1996: 4). This study is the translation product-oriented study, which in other words focuses on the translation result. This is in 
accordance with the purpose of the study, that is to find the translation techniques employed by translators in solving the equivalence issue.

The employed method in this study is descriptive qualitative with the discourse analysis approach. The descriptive qualitative method is employed with the consideration that the utilized data is qualitative data which is in the form of words, phrases, clauses, and sentences in the novel translation of Laskar Pelangi, Niji no Shonentachi. The utilized data collection technique is the observation method, which is observing the data in the novel Laskar Pelangi. Since the data of the study is the written data, in practice the researcher employs the record technique, that is taking note of several forms from the written language usage that are relevant to the study (Mahsun, 2005). The data analysis technique applied in this study is the intralingual comparison method. The intralingual comparison method is the method which compares the lingual elements both in a language and in several different languages (Mahsun, 2005). With this method, the researcher compares the data in Niji no Shonentachiwith the ones in LaskarPelangi.

\section{Findings and Discussion}

A language element is considered to have ellipsis if the element, whether in the form of word or phrase, can be understood by the interlocutors (the readers) although it has been deleted or not mentioned. On the contrary, if omitting the language element renders the interlocutors or readers to not understand what is spoken or written, the ellipsis process cannot be undergone (Kuno, 1978: 6). The subject pronoun ellipsis in a discourse cannot be separated with the sentences that compose the discourse. Ellipsis in a sentence can occur in the sentences with more than one clause.

\subsection{Phoric}

Phoric is related to the matter of reference location or the ellipsis constituent reference in a discourse element in which ellipsis occurs. Related to reference, Halliday and Hassan (1976) differed reference into two, that is the reference to the antecedent inside the discourse or intertextual which is called as endophora, and the reference to the antecedent outside the language or exophora. Based on the reference direction, endophora can be divided into anaphoric and cataphoric references (Halliday \& Hassan, 1976). Anaphoric reference is the device in language to make the cross-reference with the matter or word that is previously mentioned, while cataphoric reference is the cross-reference to the antecedent behind it (Alwi, 1998: 430). In a compound sentence or a discourse in which ellipsis occurs, it can be confirmed that one of two or more conferential constituents is in the form of noun phrase while the other is zero constituent $(\varnothing)$. The noun phrase constituent is called as controller and the constituent with ellipsis is called as controlled.

In the target language of novel translation of Laskar Pelangi, there are many subject pronoun ellipses that can be found, both anaphoric ellipsis and cataphoric ellipsis, as in data Table 1 and 2 as follows.

Table 1: Anaphoric ellipsis data

\begin{tabular}{|c|l|l|}
\hline No. & \multicolumn{1}{|c|}{ SL } & \multicolumn{1}{|c|}{ TL } \\
\hline 1 & Trapani tak tertarik dengan kelas, ia & トラパー二はクラスには興味がなく空のほ \\
& mencuri-curi pandang ke jendela, melirik & うばかり見て、Ø他の親たちに紛れてたま \\
& $\begin{array}{l}\text { kepala ibunya yang muncul sekali-sekali } \\
\text { di antara kepala orang tua lainnya. } \\
\text { (Hirata, 2005: 13) }\end{array}$ & $\begin{array}{l}\text { に見える自のの母親を探していた。 } \\
\text { (Hirata, 2013: 22) }\end{array}$ \\
\hline
\end{tabular}


Data Table 1, cont.

\begin{tabular}{|c|c|c|}
\hline 2 & $\begin{array}{l}\text {.. } \$ \text { Ia geram pada tingkah si tomboi dan } \\
\text { malu pada sang guru, seorang wanita } \\
\text { berkacamata, setengah baya, berwajah } \\
\text { cerdas dan hanya bisa tersenyum- } \\
\text { senyum. \&beliau tak henti-henti memohon } \\
\text { maaf pada wanita Jawa yang sangat } \\
\text { santun itu atas kelakuan anaknya. ... } \\
\text { (Hirata, 2005: 46) }\end{array}$ & $\begin{array}{l}\text {...の彼は、手に余る自分の娘に腹を立てて } \\
\text { いる。そしてジャワ出身の気品ある中年 } \\
\text { 婦人のピアノ教師に対し、娘の態度を申し } \\
\text { 訳なく思い、何度も謝している。 ...(Hirata, } \\
\text { 2013: 44) }\end{array}$ \\
\hline
\end{tabular}

The Data Table 1 is the example of anaphoric ellipsis found in the sentences or discourse in the novel translation Niji no Shenentachi. In data 1, the sentence subject of SL Trapani is not deleted, yet is substituted with ia ("he"). In contrary, the sentence in TL which depicts the coordinate sequence relationship marked by the use of verb $\sim t e(\sim \tau)$ is deleted. The deleted part is the part marked with zero mark $(\varnothing)$. The ellipsis controller constituent in the form of nickname Torapaani (トラパー二) is on the left side of the deleted part.

In data 2 , it appears that the subject of sentence $\Phi$ of TL, that is the pronoun ia ("he"), is not deleted when reappearing as the subject of sentence $\otimes$. In sentence $\theta$, the subject $i a$ is substituted into beliau ("he"). However, ellipsis occurs in the translation of Japanese discourse in data 2 in sentence $\odot$ which has the similar subject with sentence $\Phi$. The ellipsis controller constituent, that is the pronoun kare (彼/'he"), is on the left side of the deleted part.

Beside the anaphoric ellipsis, though less, the cataphoric ellipsis is also found in the compound sentences and discourse of novel translation Niji no Shonentachi, as seen in Data Table 2.

Table 2: Cataphoric ellipsis data

\begin{tabular}{|c|c|c|}
\hline No. & SL & TL \\
\hline 3 & $\begin{array}{l}\text { Setelah dimarahi seperti itu biasanya Harun } \\
\text { tersenyum kecil dan memperhalus } \\
\text { tabuhannya. } \quad \text { (Hirata, 2005: 147) }\end{array}$ & $\begin{array}{l}\text { ФØそうやって怒られると、のハルンはた } \\
\text { いてい小さく微笑んで、るØ丁寧に叨い } \\
\text { て見せる。(Hirata, 2005: 122) }\end{array}$ \\
\hline 4 & $\begin{array}{l}\text { Фada kesempatan lain, karena masih kecil } \\
\text { tentu saja, kami sering mengeluh mengapa } \\
\text { sekolah kami tak seperti sekolah-sekolah } \\
\text { lain. } \text { Terutama atap sekolah yang bocor } \\
\text { dan sangat menyusahkan saat musim hujan. } \\
\text { 3 Beliau tak menanggapi keluhan itu tapi } \\
\text { mengeluarkan sebuah buku berbahasa } \\
\text { Belanda dan memperlihatkan sebuah } \\
\text { gambar. (Hirata, 2005: } 31 \text { ) }\end{array}$ & $\begin{array}{l}\text { Фまたある時、Ø他の学校のように立派 } \\
\text { な建物がないことについて不を言った } \\
\text { ことがある。のとくに雨季に雨漏りする } \\
\text { 屋根にはうんざりだった。るしかしム } \\
\text { 先生は僕たちの文句にはとりあおうとせ } \\
\text { ず、代わりにあるオランダ語の本を取り } \\
\text { 出し、一枚の絵を見せてくれた。 } \\
\text { (Hirata, 2013: 33) }\end{array}$ \\
\hline
\end{tabular}

In Table 3, ellipsis occurs in a sentence with three clauses. The subject ellipsis occurs in the first and third clause, and the ellipsis controller in the form of nickname Harun is in the second clause. In clause $\infty$, the occurred ellipsis is cataphoric ellipsis since the ellipsis controller is placed after the controlled constituent. The ellipsis in clause 3 is the ellipsis since the ellipsis controller constituent is placed before the controlled constituent.

Data 4demonstrates that in the SL, the subject of the sentence@that iskami ("we"), is not deleted. Meanwhile in the TL, the subject of the sentence®, that is bokutachi (僕たち/"we”) is deleted. The ellipsis controller constituent of sentence $\odot$ is 4 able 3 in al bokutachi (僕たち /"we") which is placed on the right side of the controlled constituent (sentence 3 )of subject pronoun. 
From the description in Table $1 \& 2$, it can be deduced that in the Japanese sentences and discourse, the ellipsis controller constituent can be on the right or left side of the controlled constituent. The subject pronoun ellipsis in data number 1 and 3 is in line with Noda's (1991) statement that in Japanese, the subject ellipsis is common in compound sentences since the subject or the object might be similar in the sentences. Thus, although there is subject ellipsis in sentence 1 and 3, the subject can be recognized due to the subject consistency in the main and subordinate clauses. Besides the subject consistency in the main and subordinate clauses, Noda (1991) also stated that ellipsis can occur in two or more continuous sentences. If there are two or more continuous sentences have the same subject as in example 2 and 4, then one of the sentence subjects can be deleted.

\subsection{Functions and Roles of ellipsis controller}

The functions of a sentence's constituent are highly related to the constituent's roles and its structural relationship with other constituents. Generally, the possible syntactic functions owned by a constituent are subject, predicate, object, adverb, and complement. However, whether those syntactic functions are possessed by subject ellipsis controller constituent depends on the constituent's role. The following are the syntactic functions and roles in the SL novel Laskar Pelangi by Andea Hirata.

Table 3: Functions and Roles of Ellipsis Controller

\begin{tabular}{|c|l|c|c|c|c|}
\hline No & $\begin{array}{l}\text { Syntactic Function } \\
\text { Roles }\end{array}$ & S & O & Com & Adv \\
\hline 1 & Agent & $\sqrt{ }$ & $\sqrt{ }$ & $\mathrm{X}$ & $\mathrm{X}$ \\
\hline 2 & Recipient & $\sqrt{ }$ & $\sqrt{ }$ & $\mathrm{X}$ & $\mathrm{X}$ \\
\hline 3 & Experiencer & $\sqrt{ }$ & $\sqrt{ }$ & $\mathrm{X}$ & $\mathrm{X}$ \\
\hline 4 & Beneficiary & $\sqrt{ }$ & $\sqrt{ }$ & $\mathrm{X}$ & $\mathrm{X}$ \\
\hline 5 & Attribute & $\sqrt{ }$ & $\mathrm{X}$ & $\mathrm{X}$ & $\mathrm{X}$ \\
\hline
\end{tabular}

The ellipsis controlled function in the form of subject pronoun in Japanese, if it is related to the ellipsis controller functions, can be confirmed to solely have the roles of subject, object, complement, and adverb. Then, if it is connected to the ellipsis controller roles, since the controlled are the subject pronouns, the possible roles of the ellipsis controller are agent, recipient, experiencer, and beneficiary.

Table 4: Data of Roles and Functions of Ellipsis Controller Constituent

\begin{tabular}{|c|c|c|}
\hline No. & SL & TL \\
\hline 5 & $\begin{array}{l}\text { (1) Dia duduk sendirian menabuh Tabla, } \odot \\
\text { mencari-cari musik, } 3 \text { sampai sore di bawah } \\
\text { filicium. (Hirata, 2005: 223) }\end{array}$ & 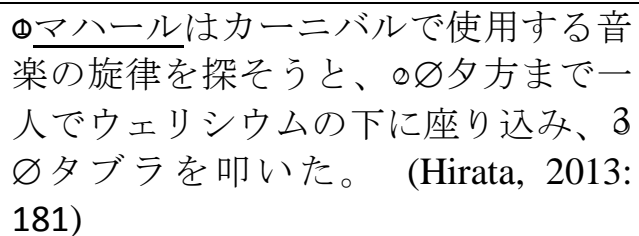 \\
\hline
\end{tabular}


Table 4, cont.

\begin{tabular}{|c|c|c|}
\hline 6 & $\begin{array}{l}\text { (1) Asap itu membuat penghuni rumah } \\
\text { terbatuk-batuk, namun ia amat diperlukan } \\
\text { guna menyalakan gemuk sapi yang dibeli } \\
\text { bulan sebelumnya dan digantungkan } \\
\text { berjuntai-juntai seperti cucian di atas } \\
\text { perapian. } \odot \text { Gemuk sapi itulah sarapan mereka } \\
\text { setiap pagi. 3Sebelum berangkat para kuli itu } \\
\text { tidak minum teh Earl grey atau Cappuccino, } \\
\text { melainkan minum air gula aren dicampur } \\
\text { jadam untuk menimbulkan efek tenaga } \\
\text { kerbau yang akan digunakan sepanjang hari. } \\
\text { (Hirata, 2005: 53) }\end{array}$ & 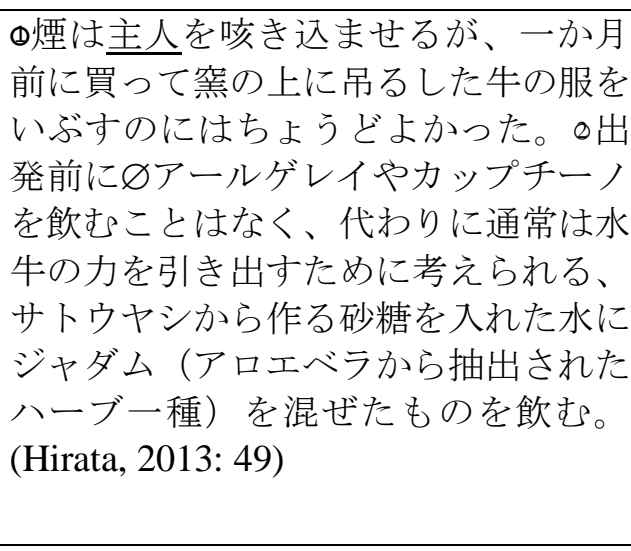 \\
\hline 7 & $\begin{array}{l}\text { @ Kami terperangah dan Bu Mus terkejut. } \odot \\
\text { Prolog semacam ini tak pernah kami lakukan, } \\
\text { dan tema lagu pilihan Mahar sangat tak biasa. } \\
\text { (Hirata, 2005: 135) }\end{array}$ & $\begin{array}{l}\text { @ムス先生と僕たちは驚いた。 } 2 \varnothing こ ん ~ \\
\text { なプロローグはこれまで一度も見たこ } \\
\text { とがない。(Hirata, 2013: 111) }\end{array}$ \\
\hline 8 & $\begin{array}{l}\text { ФKepala sekolahnya adalah seorang pejabat } \\
\text { penting, Ibu Frischa namanya. } \odot \text { Caranya ber- } \\
\text { makeup jelas memperlihatkan dirinya sedang } \\
\text { bertempur mati-matian melawan usia dan } \\
\text { tampak jelas pula, dalam pertempuran itu, } \\
\text { beliau telah kalah. (Hirata, 2005: } 60 \text { ) }\end{array}$ & 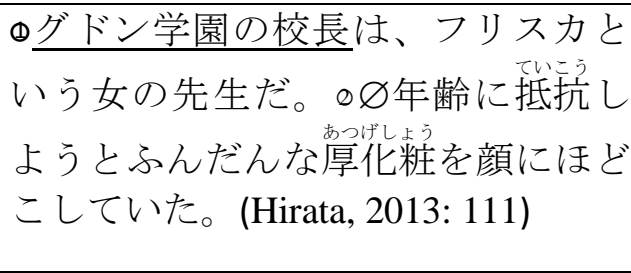 \\
\hline
\end{tabular}

Anaphoric ellipsis occurs in data 5 of TL which is a compound sentence with similar subject. The ellipsis controller Mahar (マハール)functions as a subject and has the agent role. The subject which plays as an agent can be found in the clause with the predicate of action verb, such as in the verbsagasu which becomes the basic verb sagasou (探そう/"look for”). In data 6, cataphoric ellipsis occurs in the discourse of Laskar Pelangi. The ellipsis controller, that is shujin (主人/"husband"), that is placed in the causative sentenceøfunctions as an object by being marked with accusative case particle wo (を) which follows it. The subject person ellipsis can occur in such causative sentence if the subject is not human being since if it happens, it will confuse the interlocutors and readers.

Data 7 is an example of discourse ellipsis controller which functions as a subject and has the experiencer role. Experiencer is the participant who experiences a condition or event stated by the predicate. The subject which has the experiencer role is the subject whose predicate is an adjective or intransitive verb which states a condition (Alwi, 1998: 335). The anaphoric ellipsis controller in data 7, that isMusu sensei to bokutachi (ムス先生と僕たち/"Mrs Mus and us") owns intransitive verb odoroita (驚いた/"being surprised") as the predicate. Anaphoric ellipsis also occurs in data 8 which is a discourse with a sentence whose subject is continuous. The ellipsis controller is Gudon Gakuen no Kouchou (グドン学園の校長 /"Gudong's Headmaster") which functions as a subject with the role. From the explication above, it can be concluded that the functions and roles owned by an ellipsis controller is limited since the ellipsis controlled constituent is restricted to has the function as the subject pronoun.

\section{Conclusion}

The ellipsis of subject pronoun occurs in the Japanese novel translation of Laskar Pelangi, although in the source language, the source repetition is avoided by doing substitution and pronoun usage. This ellipsis occurs since Japanese characteristics as the target language differs from Bahasa Indonesia. In Japanese, to avoid repetition, the subject ellipsis is possible to 
do. This happens since in Japanese, a subject of a sentence can be found by seeing the verb that becomes the predicate of the sentence, there is a subject consistency in the main and subordinate clauses at the compound sentence level, and at the discourse level of two or more sentences that are continuous and have the same subject, one of the subjects can be omitted. From the conclusion, the translators who will translate the discourse of Bahasa Indonesia into Japanese can consider these matters. In Japanese, the subject pronoun ellipsis is not possible if the subject and the object are human beings.

\section{References}

Alwi, H., et al. 1998. Tata bahasa baku bahasa Indonesia. Jakarta: Balai Pustaka. Halliday, M.A.K., \& Hasan, R. 1979. Cohession in English. London: Longman Hirata, A. 2006. Laskar pelangi. Yogyakarta: Bentang.

Hirata, A. 2013. Niji no shonentachi. Translated by Katou Hiroaki. Tokyo: Sunmark.

Kuno, S. 1978. Danwa no bunpou. Tokyo: Taishukan Shoten.

Mahsun. 2005. Metode penelitian bahasa. Tokyo: Kuroshio Shuppan.

Noda, H. 1991. Hajimete no hito no nihongo bunpou. Tokyo: KurshioShuppan. 